The Insurgent Barricade 
The publisher gratefully acknowledges the generous support of the Ahmanson Foundation Humanities Endowment Fund of the University of California Press Foundation. 


\title{
The Insurgent Barricade
}

\author{
Mark Traugott
}

\section{甲}

UNIVERSITY OF CALIFORNIA PRESS

Berkeley Los Angeles London 
University of California Press, one of the most distinguished university presses in the United States, enriches lives around the world by advancing scholarship in the humanities, social sciences, and natural sciences. Its activities are supported by the UC Press Foundation and by philanthropic contributions from individuals and institutions. For more information, visit www.ucpress.edu.

University of California Press

Berkeley and Los Angeles, California

University of California Press, Ltd.

London, England

(C) 2010 by The Regents of the University of California

Library of Congress Cataloging-in-Publication Data

Traugott, Mark.

The insurgent barricade / Mark Traugott.

p. $\mathrm{cm}$.

Includes bibliographical references and index.

ISBN 978-0-520-26632-2 (cloth : alk. paper)

1. Revolutions-Europe-History-19th century 2. RevolutionsEurope-History-18th century. 3. Insurgency-Europe-History19th century. 4. Insurgency-Europe-History-18th century.

5. Europe-History, Military-19th century. 6. Europe-History, Military-18th century. 7. Barricades (Military science)-Social aspects-Europe-History-19th century. 8. Barricades (Military science)-Social aspects-Europe-History-18th century.

D299.T68 2010

363.32'309409033-dc22

2010018190

Manufactured in the United States of America

$\begin{array}{llllllllll}19 & 18 & 17 & 16 & 15 & 14 & 13 & 12 & 11 & 10\end{array}$

$\begin{array}{llllllllll}10 & 9 & 8 & 7 & 6 & 5 & 4 & 3 & 2 & 1\end{array}$

This book is printed on Cascades Enviro 100, a 100\% post consumer waste, recycled, de-inked fiber. FSC recycled certified and processed chlorine free. It is acid free, Ecologo certified, and manufactured by BioGas energy. 
To Patticat

for your willingness to always stand on the same side of all my barricades 
This page intentionally left blank 